\title{
The Pennsylvania 2015 State Supreme Court Election in Comparative Perspective
}

\author{
JENNA BECKER KANE
}

West Chester University

Judicial candidates and outside groups spent a record \$15.8 million in a 2015 election that decided the partisan balance of the Pennsylvania Supreme Court. Adding to the record-setting election was a barrage of televised attack advertising in which outside interests spent over $\$ 4$ million to influence the outcome of the high court race. This article places the 2015 Pennsylvania Supreme Court election in comparative perspective to assess whether or not the campaign fundraising, campaign spending, and campaign advertising in this race was as "historic" as commonly claimed. Interestingly, when compared with other Pennsylvania high court races, the 2015 race was not a watershed election for candidate fundraising, especially when fundraising totals are averaged per candidate. Neither was the tone and tenor of campaign advertising in the 2015 Pennsylvania race outside the trend of contemporary judicial campaigns in other states, which have seen a marked increase in televised attack advertising by outside groups that often target candidates as soft on crime. Overall, the cost and tone of the 2015 Pennsylvania Supreme Court race appears to be a part of wider trends in contemporary judicial elections and very much in line with the cost of high court races in Pennsylvania over the last decade. The article concludes by surveying empirical evidence on the efficacy of judicial elections and assesses Pennsylvania's prospects for reforming its method of judicial selection. 
he weeks leading up to the November 2015 election in Pennsylvania reminded citizens of an oft-forgotten caveat of Pennsylvania politics-that here in the Keystone state, judges are elected. Elections cost money, which often means that candidates seeking judicial office must raise money and actively campaign for votes much like those in the legislative and executive branches. Voters experienced this reality firsthand in November when seven candidates vied for three vacancies on Pennsylvania's highest court in an expensive, high-stakes election that would decide the partisan balance of the court and have wide-ranging effects for most matters of state law.

Perhaps the most visible evidence of this high-stakes political battle for the Pennsylvania bench was the barrage of television advertising that was seen across the state in the final weeks of the campaign, some of which turned negative. One ad accused a candidate of falsely claiming authorship of published legal articles and filing improper information on campaign finance forms. Another accused a candidate of "failing to protect women and children" and handing down "lenient sentences," while still another ad accused a candidate of failing "to protect a child" and allowing "a young girl to be placed in the custody of a convicted murderer."

News reports and editorials declared the 2015 Pennsylvania Supreme Court race "the most expensive judicial election in U.S. history" (Bishop 2015) and decried the use of attack advertising in the judicial contest as a "low road to [the] high court" (Philadelphia Inquirer Editorial Board 2015). In fact, most media coverage of the 2015 Pennsylvania judicial elections espoused one of two major objections (either explicitly or implicitly) to the raucous nature of the high court election. First, many accounts raised concerns about the amount of money raised and spent by candidates vying for the three open seats in Pennsylvania; the race cost in excess of $\$ 15.8$ million, which surpassed the previous national record of $\$ 15.19$ million set by a 2004 race in Illinois (Brennan Center for Justice 2015). ${ }^{2}$ The second major objection takes aim at the tone and source of the campaign advertising used in the 2015 election, which brought an onslaught of negative campaign advertisements sponsored by interest groups, many from outside the state. Concerns like these over the cost and tone of Pennsylvania's recent judicial election echo many of those shared by many in the legal community who believe the realities of campaign fundraising and advertising in judicial elections erodes judicial independence and threatens the legitimacy of the courts. In fact, these concerns run so deep that the 2015 election catapulted judicial selection reform back onto the state's legislative agenda with widespread bipartisan support. 


\section{Significance of the 2015 Pennsylvania Supreme Court Race}

On November 3, 2015, seven candidates (originally 12 when the primaries began) competed for three open seats on the Pennsylvania Supreme Court. While this election was historic in regards to campaign fundraising and the influx of spending by outside groups, this high court race also saw a record number of candidates vying for the most open seats in the court's history. All of these record-setting benchmarks came as a result of years of controversy and scandal that rocked Pennsylvania's highest judiciary.

The first vacancy occurred as a result of the suspension and subsequent resignation in 2013 of Republican Justice Joan Orie Melvin after being convicted of six counts of campaign corruption. The charges stemmed from Melvin's use of her superior court staff to help organize and run her 2003 and 2009 election bids for the state supreme court and for her involvement in using the campaign staff of her sister, then state senator Jane Orie, to assist her own campaign for the state high court. The second vacancy resulted from the 2014 suspension of Justice Seamus McCaffery, a Democrat, for his involvement in a scandal involving the exchange of sexually explicit emails between members of the state Attorney General's Office and other state employees. McCaffery resigned one week after his October 20, 2014, suspension. The court's third vacancy arose with Republican Chief Justice Ronald Castille's retirement in January 2015 after reaching the mandatory retirement age of 70 the previous year. ${ }^{3}$

With three vacancies, the partisan composition of Pennsylvania's sevenmember court was evenly divided between two sitting Republican justices and two sitting Democrats, making the outcome of the 2015 election crucial for deciding the ideological direction of the state's highest court. This fact alone heightened the political importance and policy implications of the 2015 Pennsylvania Supreme Court race. In recent years, the Pennsylvania high court has decided issues related to education funding, redistricting procedures, voter identification requirements, and fracking. Perhaps most significant, the partisan composition of the court could be vital to determining party control of the state's Legislative Reapportionment Commission, which may play a role in future state redistricting decisions. The Commission comprises five members, four of whom are selected respectively by the majority and minority leadership of both chambers. The Pennsylvania Supreme Court is charged with selecting the fifth member as chair of the committee if the four selected members cannot agree on an appointment, thus positioning the state supreme court to select the partisanship of the tie-breaking vote on the commission. 
methods used across the states to staff state supreme courts. Seven states use partisan elections to select state high court judges. In these contests, judges are selected by political parties in partisan primaries. Winners of the partisan primaries face each other in general elections in which the party affiliation of each candidate appears on the ballot. Sixteen states use nonpartisan elections to choose judges. In these contestable elections, candidates must compete in nonpartisan primaries to run in the general election where the party identification of candidates is excluded from the ballot.

Another sixteen states use the Missouri Plan to select judges. The Missouri Plan is a commission-based system of selection that uses a judicial nominating commission to screen judicial candidates and make recommendations from which the governor must choose. These appointments are usually then subject to confirmation in the state senate. To secure subsequent terms, judges must run in uncontested retention elections in which there are no challengers and voters are simply asked to award a sitting judge another term in a yes/no vote.

The final method of selecting judges in the states is through appointment. Ten of the 12 appointment states use gubernatorial appointment with legislative confirmation, which largely resembles the federal system of selection. Two states-South Carolina and Virginia-allow their legislatures to appoint high court judges. Under all of these appointment systems, judges must seek reappointment by the governor or legislature to secure subsequent terms.

Despite these broad categories of judicial selection methods, there is much variation both across and within states. Pennsylvania is a good example of this variation. Pennsylvania uses partisan elections to initially select state supreme court judges to 10-year terms, but then uses uncontested retention elections to retain judges for subsequent terms. This means that state judges face competitors in contestable elections to initially ascend to the bench, but thereafter run unopposed. Pennsylvania is also one of only two states that hold judicial elections in off-years to coincide with municipal elections, which greatly lowers turnout in these elections.

\section{The Price of Judicial Elections}

In total, 38 states use some form of elections to select or retain judges-either partisan, nonpartisan, or retention elections. For much of the twentieth century, judicial elections were low-key affairs that garnered little public attention and demanded very little in the way of campaign fundraising. However, since the 1990s, state supreme court races have become more competitive (Bonneau 2005; Hall 2001, 2007; Kritzer 2011), more contested (Bonneau and Hall 2003; Hall 2001), and more expensive (Bonneau 2004; Sample et al. 2010). Using 
data collected by the Justice at Stake Campaign, Brennan Center for Justice, and National Institute on Money in State Politics, Figure 1 shows aggregate campaign fundraising totals in all state supreme court races since the mid1990s. Several trends are evident. First, the cost of high court elections appears to have increased in recent decades, but this increase has not been monotonic. Campaign fundraising increased steadily throughout the 1990s, but thereafter appears to vary largely with presidential election cycles. The cost of high court races held in presidential election years was substantially greater than in those held in off-year elections throughout the 2000s. The final observation to be made from Figure 1 is that aggregate levels of campaign fundraising in high court races appear to be returning to levels similar to those in the 1990s. In fact, aggregate candidate fundraising in 2013-2014 was the lowest in the timeframe being observed, which may be a result of an unprecedented number of uncontested races in the 2013-2014 election cycle (Greytak et al. 2015) or may be symptomatic of a larger downward trend in campaign fundraising by high court candidates. Only future data will shed light on the true nature of this trend.

Not all elections are created equal when it comes to campaign fundraising and spending in state supreme court races. Retention elections inherently involve very low levels of overall spending due to their uncontested nature. Indeed, most retention elections see no campaign spending or advertising at all. This is evident in Figure 2, which shows overall spending totals in state

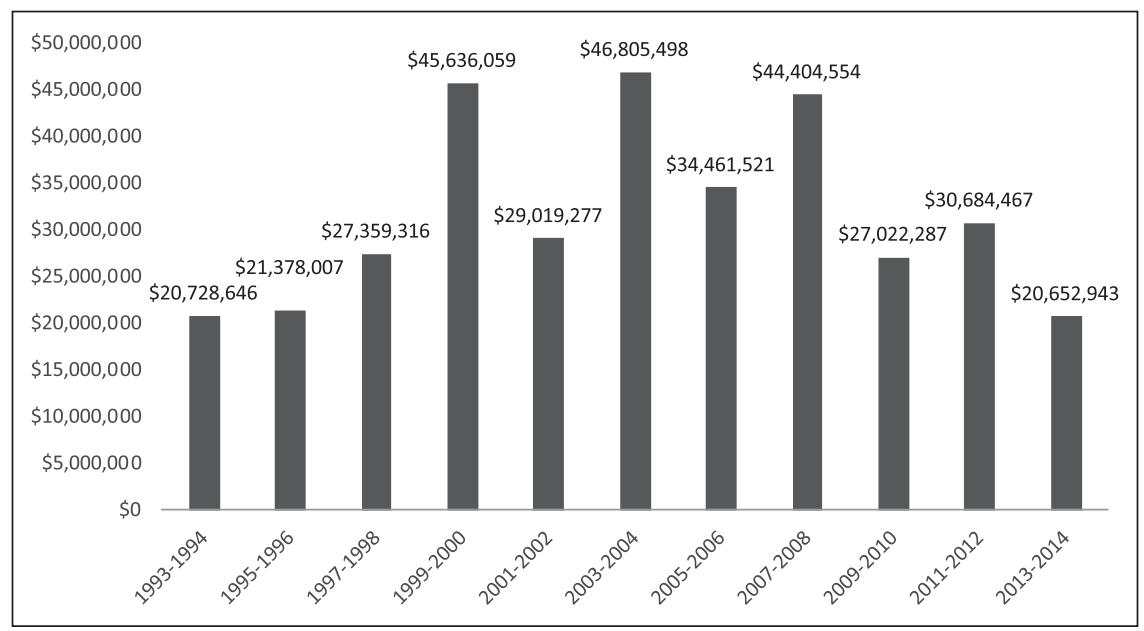

Figure 1. Total Candidate Fundraising in State Supreme Court Elections. (Compiled by the author from data presented in the New Politics of Judicial Elections series [Washington, DC: Justice at Stake Campaign].) 


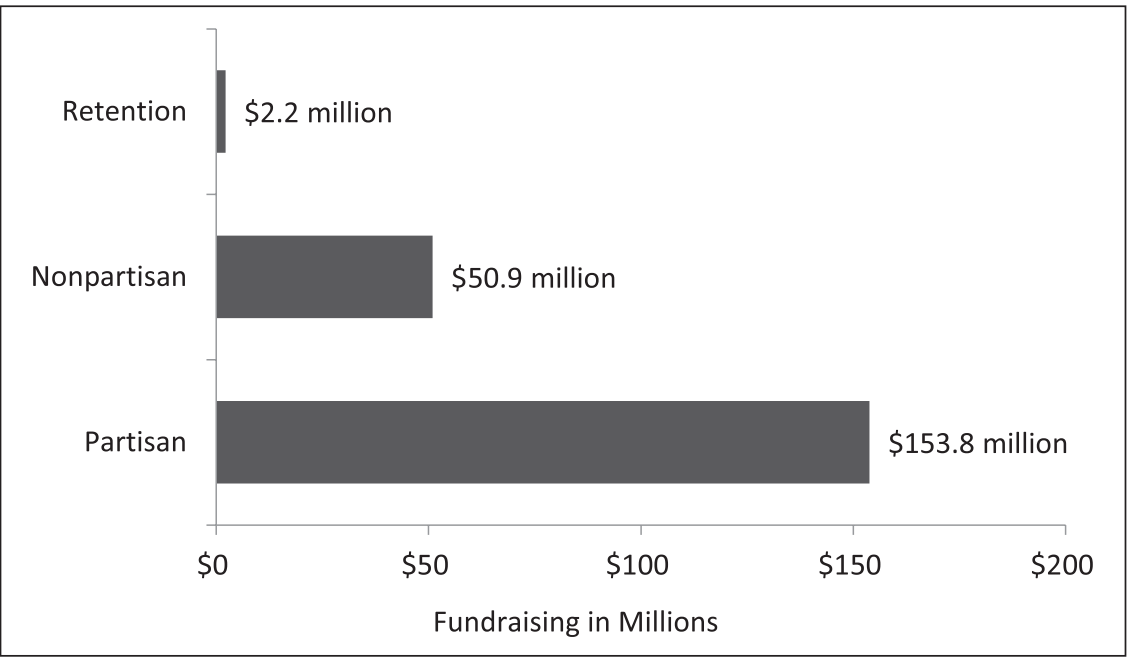

Figure 2. Total Spending in State Supreme Court Elections by Election Type, 2000-2009. (Data from James Sample et al., The New Politics of Judicial Elections 2000-2009: Decade of Change [Washington, DC: Justice at Stake Campaign, 2010].)

high court elections between 2000 and 2009 separated by election type. Partisan elections are by far the most expensive of all of high court contests. Partisan races have historically attracted far greater levels of campaign spending than have nonpartisan and retention elections. Given the fact that political parties are actively involved in partisan state supreme court campaigns, perhaps it is unsurprising that these contests routinely see the highest levels of spending.

\section{Pennsylvania in Comparative Perspective}

Campaign Fundraising/Spending

The Pennsylvania 2015 Supreme Court election cost in excess of \$15.8 million with just over $\$ 13$ million of that raised through candidate fundraising efforts. As we saw in Figure 2, partisan elected state high court races are traditionally the most expensive judicial races. In fact, Table 2 shows that Pennsylvania high court races are routinely amongst the most costly of all state supreme court elections. In fact, from 2000-2009 Pennsylvania was home to the third most expensive set of high court races with aggregate spending totals exceeding \$22 million. With total spending exceeding \$15.8 million in the 2015 contest alone, Pennsylvania appears to be well on its way to breaking its total spending records from the previous decade. 


\begin{tabular}{|c|c|}
\hline State & Total Spending \\
\hline Alabama & $\$ 43,587,170$ \\
\hline Ohio & $\$ 29,834,992$ \\
\hline Pennsylvania & $\$ 22,653,882$ \\
\hline Texas & $\$ 20,717,067$ \\
\hline Illinois & $\$ 20,695,352$ \\
\hline Michigan & $\$ 18,603,443$ \\
\hline Mississippi & $\$ 12,084,774$ \\
\hline Wisconsin & $\$ 11,540,219$ \\
\hline Nevada & $\$ 9,888,121$ \\
\hline West Virginia & $\$ 9,566,132$ \\
\hline
\end{tabular}

All of the states with the most expensive high court races are states that use partisan elections to select judges. This is in large part because most state campaign finance laws that dictate how funds can be raised for legislative and executive state-level races also apply to partisan judicial races, allowing for funds to be easily raised by candidates. However, a few limits are regularly placed on judicial elections that are not placed on candidates running for other state-level offices. In Pennsylvania specifically, there are no limits on the amount of money individuals can contribute to judicial campaigns as long as contributions are not anonymous and cash contributions do not exceed $\$ 100$. Direct campaign contributions from corporations, labor unions, and regulated industries to judicial campaigns are prohibited. However, there are no limits on the amounts that political action committees (PACs), often set up by corporations and labor unions, can contribute to judicial candidates. ${ }^{4}$ Pennsylvania's judicial code of conduct also bars candidates from directly soliciting or accepting campaign contributions, but candidate campaign committees are not barred from such activity. ${ }^{5}$ Therefore, despite some limitations on the campaign fundraising of judicial candidates in Pennsylvania, many viable avenues remain through which campaign contributions can freely flow.

We now know that high court contests in Pennsylvania are some of the most costly in the nation, but how does the 2015 contest compare with other recent Pennsylvania supreme court races? Table 3 helps to shed some light on that question by comparing campaign fundraising totals for recent open-seat Pennsylvania high court elections. Data reveal that while the 2015 high court 


\begin{tabular}{|c|c|c|c|c|}
\hline Year & Candidate & Total Raised & $\begin{array}{l}\text { Total for } \\
\text { Race* }\end{array}$ & $\begin{array}{l}\text { Average } \\
\text { Per-Candidate } \\
\text { Fundraising }\end{array}$ \\
\hline \multirow{7}{*}{$\begin{array}{l}2015 \\
\text { (3 seats) }\end{array}$} & Christine Donohue (D) won & $\$ 1,951,410$ & \multirow[t]{7}{*}{$\$ 13,097,913$} & \multirow[t]{7}{*}{$\$ 1,091,493(12)$} \\
\hline & Kevin Dougherty (D) won & $\$ 3,984,375$ & & \\
\hline & David N. Wecht (D) won & $\$ 2,880,604$ & & \\
\hline & Anne Covey (R) & $\$ 984,655$ & & \\
\hline & Michael A. George (R) & $\$ 882,919$ & & \\
\hline & Judith Olson (R) & $\$ 616,330$ & & \\
\hline & Paul Panepinto (I) & $\$ 234,000$ & & \\
\hline \multirow{2}{*}{$\begin{array}{l}2009 \\
\text { (1 seat) }\end{array}$} & Joan Orie Melvin (R) won & $\$ 1,990,714$ & \multirow[t]{2}{*}{$\$ 7,666,468$} & \multirow[t]{2}{*}{$\$ 1,916,617(4)$} \\
\hline & Jack Panella (D) & $\$ 5,407,646$ & & \\
\hline \multirow{4}{*}{$\begin{array}{l}2007 \\
(2 \text { seats })\end{array}$} & Seamus McCaffery (D) won & $\$ 2,297,753$ & \multirow[t]{4}{*}{$\$ 9,464,975$} & \multirow[t]{4}{*}{$\$ 1,352,139(7)$} \\
\hline & Debra Todd (D) won & $\$ 1,594,202$ & & \\
\hline & Maureen E. Lally-Green (R) & $\$ 1,753,726$ & & \\
\hline & Mike Krancer (R) & $\$ 2,116,507$ & & \\
\hline \multicolumn{5}{|c|}{$\begin{array}{l}\text { Source: Compiled by the author from the Pennsylvania Department of State and the National Institute } \\
\text { on Money in State Politics. Available at https://www.campaignfinanceonline.state.pa.us/Pages/CFReport } \\
\text { Search.aspx and http://www.followthemoney.org/our-data/. Accessed April 25, 2016. }\end{array}$} \\
\hline
\end{tabular}

race involved the highest fundraising totals in the state's history, the average per-candidate fundraising in 2015 was not greater than that of the 2009 or 2007 open-seat elections. The 2015 race does not appear to break state records of median candidate fundraising either. The median fundraising level by candidates in 2015 was a mere $\$ 425,165$ compared to $\$ 3,699,180$ and $\$ 1,753,726$ in 2009 and 2007 respectively. Given this data, it appears that the 2009 race between Republican Joan Orie Melvin and Democrat Jack Panella was the actual "historic" high court race for campaign fundraising per candidate in Pennsylvania.

\section{Campaign Advertising}

The second major concern raised over the 2015 Pennsylvania Supreme Court election was the negative attack advertising in the final weeks of the election. A series of television ads accused Republican candidates of being "out of touch" with Pennsylvania voters, "lenient" on criminal sentences, and "dishonest," while another ad accused a Democratic candidate of failing to "keep 
our children safe" while on the bench. ${ }^{6}$ Popular accounts of the 2015 Pennsylvania Supreme Court election seem to imply that these attack ads were uncharacteristically harsh or caustic for a state supreme court election (Bishop 2015; Pittsburgh Post-Gazette Editorial Board 2015; Potter 2015). To empirically assess this concern, I use data available through the Brennan Center for Justice's Buying Time website. ${ }^{7}$ Since 2000, the Brennan Center has been collecting data on television ad airings and spending in the nation's largest media markets as calculated by Kantar Media/CMAG.

Data on the number of unique television ads aired in Pennsylvania's 2015 Pennsylvania Supreme Court race are taken from the Brennan Center's website. ${ }^{8}$ Overall, there were 21 unique advertisements aired in the 2015 Pennsylvania Supreme Court race. Consistent with standard practice (Geer 2006; Sample et al. 2010; Hall 2015), I coded each ad as either a promote ad, contrast ad, or attack ad. Promote ads are those promoting one candidate, contrast ads compare two or more candidates, and attack ads criticize a candidate. Table 4 presents the number and sponsorship of promote and attack ads for each candidate.

In the 2015 Pennsylvania race, like in most other judicial races, the majority of television ads (71\%) were designed to promote the qualifications of the candidates. While there were no contrast ads aired in this election, most likely a result of it being an open seat contest with no incumbent running for reelection, six (29\%) of the ads aired were attack ads. The very presence of attack

\begin{tabular}{|c|c|c|c|c|}
\hline Candidate & $\begin{array}{l}\text { Candidate } \\
\text { Sponsored } \\
\text { Promote Ads }\end{array}$ & $\begin{array}{l}\text { Group } \\
\text { Sponsored } \\
\text { Promote Ads }\end{array}$ & $\begin{array}{l}\text { Candidate } \\
\text { Sponsored } \\
\text { Attack Ads }\end{array}$ & $\begin{array}{l}\text { Group } \\
\text { Sponsored } \\
\text { Attack Ads }\end{array}$ \\
\hline Kevin Dougherty (D) & 4 & 0 & 0 & 1 \\
\hline David Wecht (D) & 2 & 0 & 0 & 0 \\
\hline Christine Donohue (D) & 3 & 0 & 0 & 0 \\
\hline Judy Olson (R) & 2 & 1 & 0 & 2 \\
\hline Mike George (R) & 1 & 1 & 0 & 2 \\
\hline Anne Covey (R) & 1 & 1 & 0 & 3 \\
\hline Total & 13 & $2^{*}$ & 0 & $6 * *$ \\
\hline \multicolumn{5}{|c|}{$\begin{array}{l}\text { Source: Coded by the author using data reported by the Brennan Center for Justice's Buying Time } \\
\text { website. Available at www.brennancenter.org/analysis/buying-time. The number of airings of each ad } \\
\text { is unavailable. }\end{array}$} \\
\hline \multicolumn{5}{|c|}{ *A single group-sponsored ad aired in support of Olson and Covey. } \\
\hline \multicolumn{5}{|c|}{ **A single group-sponsored ad aired attacking all three Republican candidates. } \\
\hline
\end{tabular}


advertising in the 2015 race places Pennsylvania in the minority of states that use judicial elections. In her seminal study of campaign advertising in state supreme court elections, Hall $(2015,74)$ found that only $17 \%$ (30 of 177) of all judicial elections held between 2002 and 2008 saw attack advertising. However, Hall also found that open seat elections are more likely to see attack advertising, with these elections garnering negative advertising $31.4 \%$ of the time $(2015,76)$. Therefore, the fact that three open seats were up for grabs in the 2015 Pennsylvania race, made the race more likely to see attack advertising when compared with other state supreme court contests.

Data was further coded to determine the type of appeals being made in televised ads aired in Pennsylvania's 2015 high court race. To allow comparison with Hall's work on state supreme court advertising, the content of each ad aired in the 2015 Pennsylvania race was coded using Geer's (2006) typology. Specifically, each ad was coded as discussing traits of the candidate, values of the candidate, or substantive issues. The traits category includes ads that discuss a candidate's qualifications for judicial service. The values category includes appeals that invoke family or conservative values, the proper role of judges, and restoring integrity to the bench. Ads fitting into the issues category involve specific appeals to civil justice, criminal justice, special interest influence, or criticism of past judicial decision. Figure 3 presents data on the overall tone of the ads aired in the 2015 contest.

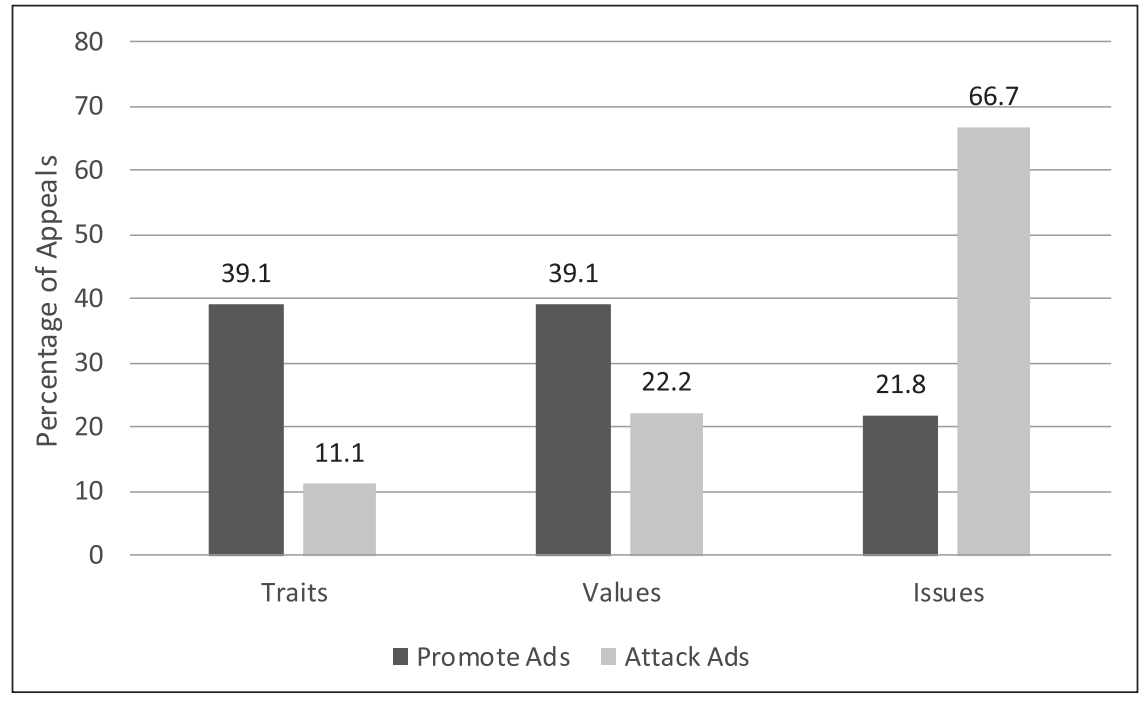

Figure 3. Types of Appeals in Televised Campaign Advertising by Tone in 2015 Pennsylvania Supreme Court Elections. (Compiled and coded by the author using data reported by the Brennan Center for Justice's Buying Time website. Available at www.brennancenter.org/analysis/ buying-time.) 
Overall there were 32 types of appeals made in 21 unique ads in the Pennsylvania 2015 supreme court race. Figure 3 shows that most promote ads aired in the Pennsylvania race focused on candidate traits and values. Most ads designed to promote individual candidates focused on specific candidate experience and qualifications and on the proper role of judges and judicial integrity. When promote ads made appeals about specific issues, those appeals focused on expanding veteran's court and reforming the state's court system. In contrast to the promote ads, $66.7 \%$ of appeals made in attack ads focused on substantive issues. Specifically, these appeals concentrated on issues of criminal justice, support by interest groups or lobbyists, and criticism for specific judicial decisions. The overall themes of these issue-based attack ads centered around candidates being "soft on crime" and candidate ties to special interest groups.

To assess whether or not the tone of candidate ads experienced by Pennsylvania voters in 2015 were outside of the norm of contemporary judicial elections, Figure 4 compares aggregate data on all televised judicial campaign ads between 2002 and 2008 with those aired in the 2015 Pennsylvania contest. Despite the fact that there were no contrast ads aired in the Pennsylvania race, the tone of ads in Pennsylvania fit quite well with trends in campaign

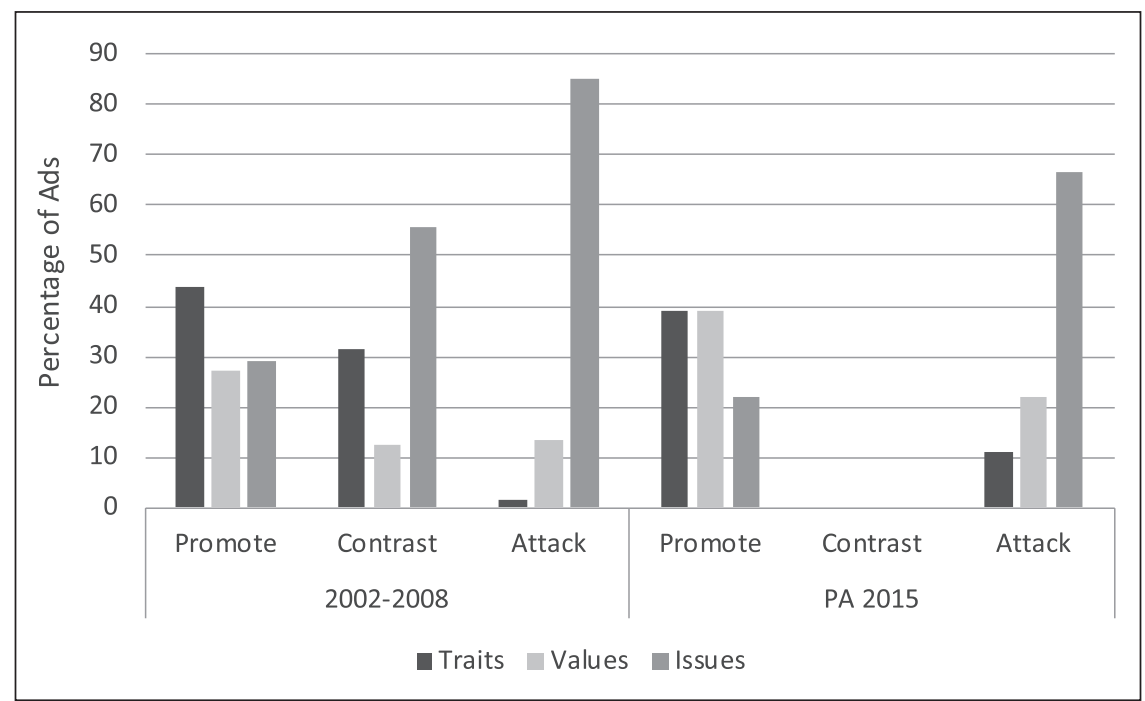

Figure 4. Types of Appeals in State Supreme Court Televised Campaign Advertising in Comparative Perspective. (Data for 2002-2008 from Melinda Gann Hall, Attacking Judges: How Campaign Advertising Influences State Supreme Court Elections [Stanford, CA: Stanford University Press, 2015], 83. Data for Pennsylvania 2015 race coded by the author using data reported by the Brennan Center for Justice's Buying Time website. Available at www.brennancenter.org/analysis/ buying-time.) 
advertising in other high court races. The tone of promote ads witnessed in the recent Pennsylvania race are in similar proportions to those seen nationally, save the slightly higher proportion of promote ads focusing on values in the Pennsylvania race. This focus on values and the proper role of judges in the Pennsylvania race should not be surprising given the recent scandals that precipitated many of the open seats on the state's highest bench. Attack ads in Pennsylvania also appear to be on par with comparative trends. Both in Pennsylvania and in other states, the vast majority of attack ads appear to make issue-specific appeals to voters.

Another important caveat of Pennsylvania's 2015 race is that candidate campaigns sponsored nearly all promote ads (13 of 15), while outside groups produced all of the negative attack ads (6 of 6). ${ }^{9}$ Table 5 presents data on the cost and sponsorship of television advertising in the Pennsylvania race. Here we see that all of the six attack ads aired were sponsored by two outside groups-Pennsylvanians for Judicial Reform and the Republican State Leadership Committee's Judicial Fairness Initiative-both of which are national independent expenditure groups, or 527 groups, based on their tax-exempt status designated by the Internal Revenue Service. These groups can sponsor independent advertising in support or opposition of candidates, but cannot advocate for the direct election or defeat of a specific candidate or coordinate their work with candidate campaigns.

In the Pennsylvania race, Pennsylvanians for Judicial Reform was funded primarily by Philadelphia trial lawyers and unions and spent nearly \$3 million airing five of the six attack ads seen by voters-all of which attacked

\begin{tabular}{|l|l|l|}
\hline Table 5. Television Advertising Spending in 2015 Pennsylvania High Court Election \\
\hline Candidate/Group & $\begin{array}{l}\text { Candidate Ad } \\
\text { Spending }\end{array}$ & $\begin{array}{l}\text { Tone of Ads } \\
\text { Supported }\end{array}$ \\
\hline Kevin Dougherty & $\$ 3,364,200$ & Promote \\
\hline David Wecht & $\$ 1,991,160$ & Promote \\
\hline Christine Donohue & $\$ 1,263,190$ & Promote \\
\hline Judy Olson & $\$ 337,980$ & Promote \\
\hline Mike George & $\$ 425,270$ & Promote \\
\hline Anne Covey & $\$ 508,540$ & Promote \\
\hline Pennsylvanians for Judicial Reform & $\$ 2,902,390$ & Attack \\
\hline Republican State Leadership Committee & $\$ 993,940$ & Attack \& Promote \\
\hline Pennsylvania Republican Party & $\$ 8,190$ & Promote \\
\hline $\begin{array}{l}\text { Source: Brennan Center for Justice's 2015 Buying Time website. Available at www.brennancenter.org/ } \\
\text { analysis/buying-time, last updated March 1, 2016. }\end{array}$ \\
\hline
\end{tabular}


Republican candidates as being unfit for office. In return, the Republican State Leadership Committee, a group whose mission it is to elect Republican candidates to down-ballot, state-level offices, spent nearly \$1 million launching a television and digital ad campaign supporting Republicans Anne Covey and Judy Olson and attacking Democrat Kevin Dougherty. The type of concentrated group spending on attack ads observed in the 2015 Pennsylvania Supreme Court election is highly consistent with recent comparative research that finds that more than $88 \%$ of the attack advertising in open seat high court contests come from political parties and outside interest groups (Hall 2015, 87).

\section{Outside Interest Group Involvement}

Another of the largest objections to the 2015 Pennsylvania supreme court race was the influx of big spending interest groups from outside the state that were responsible for the negative tone of the campaign's final weeks. As was evident from Table 5, two outside groups spent nearly $\$ 4$ million on television advertising in Pennsylvania's 2015 high court race. While spending by outside groups in judicial elections has been on the rise nationally for more than a decade (Skaggs, et al. 2011), the U.S. Supreme Court's decision in Citizens United v. Federal Election Commission 558 U.S. 310 (2010) is often credited as the major impetus to outside group involvement in judicial campaigns. In Citizens United, the Supreme Court struck down a provision of the Bipartisan Campaign Reform Act that prohibited corporations, unions, and nonprofit organizations from spending money on independent expenditures and electioneering communications in support or opposition of candidates running for office. Essentially, the Court's ruling established that groups had the same free speech rights as individuals to spend money on independent advertisements in support (or opposition) of electoral candidates. Thus, since Citizens United removed limits to independent expenditures, there has been a proliferation of group-funded super-PACs engaging in campaign advertising in the electoral arena, including state supreme court races.

Did the Citizens United decision contribute to an increase in campaign advertising by outside groups in the 2015 Pennsylvania Supreme Court race? That question is not easily answered with existing data, but the Court's decision has definitely opened state supreme court races to independent advertising that is outside the control of candidate campaigns. Table 6 presents data on television advertising aired in Pennsylvania's most recent open-seat supreme court contests. While there is limited available data on independent expenditures on televised advertising in Pennsylvania high court races, there 
Table 6. PA Supreme Court Television Advertising Spending by Election Cycle

\begin{tabular}{|l|l|l|l|l|}
\hline Year & Candidate & Group & Party & Total \\
\hline 2015 (3 open seats) & $\$ 8,496,200$ & $\$ 3,896,330$ & $\$ 8,190$ & $\$ 12,400,720$ \\
\hline $2009^{*}$ ( 1 open seat) & NA & NA & NA & $\$ 3,346,302$ \\
\hline 2007 (2 open seats) & $\$ 3,500,454$ & $\$ 858,611$ & $\$ 196,131$ & $\$ 4,555,196$ \\
\hline
\end{tabular}

Source: Compiled by the author from data presented in the New Politics of Judicial Elections series (Washington, DC: Justice at Stake Campaign) and by the Brennan Center for Justice's Buying Time website. Available at www.brennancenter.org/analysis/buying-time.

*Disaggregated data for the 2009 election are unavailable.

does appear to be a sharp jump in group spending from the 2007 race to the first post-Citizens United open seat contest in $2015 .{ }^{10}$ Outside groups went from spending just over $\$ 1$ million on advertising in 2007 to just over $\$ 4$ million in the 2015 campaign. However, without disaggregated totals for outside spending in the 2009 campaign, any conclusions drawn from this data must be made extremely cautiously. Despite the spike in outside spending in Pennsylvania's 2015 race, it is premature to say if the documented increase in interest group spending in 2015 will continue in future open seat contests.

\section{Judicial Elections}

\section{A Threat to Judicial Legitimacy?}

For decades, legal associations, ${ }^{11}$ advocacy groups, ${ }^{12}$ and legal scholars have trumpeted the deleterious effects of elections on judicial independence and court legitimacy. For many of those in the legal academy, including former Supreme Court Justice Sandra Day O'Connor, judicial elections and all that running for office entails present conflicts of interest for judges and erode the public's faith in America's courts (O'Connor 2008).

Is justice for sale when judges are forced to raise money and campaign for votes? Does subjecting judges to popular votes diminish citizen perception of the judiciary? The 2015 supreme court race in Pennsylvania highlighted these fundamental questions about the efficacy of judicial elections. Anecdotal evidence abounds to support these criticisms of judicial elections, but systematic, empirical evidence suggests that judicial elections are not as dangerous to court legitimacy as may be popularly believed.

Those concerned that justice is for sale often argue that the high cost of judicial elections forces candidates to raise large sums of money, mostly from attorneys, who will argue cases before the judge they contribute to, or 
from groups and corporations that frequently have litigation pending before the court. This raises serious concerns that judicial elections make judges beholden to campaign contributors rather than the rule of law (Hansen 1998; Sample et al. 2010). For instance, a 2010 study commissioned by Pennsylvanians for Modern Courts found that $60 \%$ of civil cases heard by the Pennsylvania Supreme Court in 2008 and 2009 involved litigants or lawyers who had contributed to the election campaigns of at least one of the state's high court justices (American Judicature Society 2010a). This type of anecdotal evidence certainly raises concern about the fairness or impartiality of courts that routinely decide cases in which campaign contributors are involved. However, empirical evidence on the influence of campaign contributions on judicial decisions is mixed. Some scholars have found a correlation between contributions and decisions (Cann 2007; Shepherd 2009, 2013), while others have not (Cann 2002; Cann, Bonneau, and Boyea 2012). What is challenging in this line of inquiry is determining causal effects from correlational measures. Difficulty arises when attempting to untangle whether a judge's vote in favor of a contributing attorney is a result of the attorney's campaign donation or a result of an attorney's decision to contribute to a judge who is already predisposed to vote in favor of the attorney's litigants. In technical terms, there is a problem of endogeneity that makes determining the true relationship between campaign dollars and decisions methodologically difficult.

Despite mixed evidence on the relationship between donations and judicial decisions, empirical studies have found some positive effects of high-cost judicial elections. Judicial elections have been found to have democraticenhancing effects, such as mobilizing voters and decreasing ballot roll-off in state high court contests (Bonneau and Hall 2009). Partisan judicial elections have also been found to provide voters with valuable information about candidates for judicial races that help voters make decisions about otherwise low-information races (Baum 2003).

However, there are real concerns in the legal community that judicial elections and raucous campaigns like the 2015 Pennsylvania race erode the legitimacy of the courts, and there is some validity to these concerns. Data from various statewide surveys suggest that judicial elections and campaign fundraising raise some concerns over the legitimacy of the courts for a majority of the publics polled (Bonneau and Hall 2009) and that citizens living in states with elected courts have lower levels of confidence in their court systems compared with those in states with appointed courts (Benesh 2006). In Pennsylvania specifically, a 2010 survey showed that $76 \%$ of survey respondents believed that campaign contributions influence judicial decisions (American Judicature Society 2010b). 
However, evidence suggests that judicial elections are not as legitimacyeroding as popular opinion polls may lead us to believe. Using a set of sophisticated survey experiments, Gibson (2012) found that voters tend to favor accountability over independence when it comes to choosing state judges and thus, judicial elections actually elevate citizen support of state courts as an institution. Despite this legitimacy-enhancing effect of judicial elections, Gibson also finds evidence to suggest that attack advertising and raucous judicial campaigns erode court legitimacy to some degree. Ultimately, Gibson concludes that judicial elections are a "mixed bag, with some positive influences on citizens but with negative consequences as well” $(2012,127)$.

\section{Is Judicial Selection Reform in Pennsylvania's Future?}

The interest-group-fueled 2015 state supreme court race and a judiciary riddled with scandals resurrected a long-standing debate in Pennsylvania politics about reforming the method of judicial selection in the Keystone state. Proponents of court reform, such as the group Pennsylvanians for Modern Courts, have long argued that a commission-based appointment system like the Missouri Plan, also called merit selection, would eliminate the need for judicial candidates to raise money and mount campaigns for office, thus eliminating any perception of quid pro quo relationships between judges and litigants. Commission-based systems are also heralded as a way to ensure higher quality and more diverse candidates reach the bench. However, critics of the merit selection contend that commission-based systems are "propagandistic misnomer[s]" (Dimino 2004, 803) that allow political elites to install judges with no electoral accountability and produce judges with no appreciable difference in qualifications or professional experience (Goelzhauser 2016).

While this type of reform has percolated in Pennsylvania politics for decades-former Governors Tom Ridge and Ed Rendell were both strongly committed to reform-little legislative movement has been made over the years to accomplish this goal. However, progress was made on October 20, 2015, when the Pennsylvania House Judiciary Committee voted to endorse House Bill 1336 in a 16 to 11 bipartisan vote. House Bill 1336 is a proposed amendment to the Pennsylvania Constitution that would replace the current partisan election of appellate state judges with a commission-based appointment system in which the governor would appoint candidates (with Senate confirmation) to fill judicial vacancies that are recommended by an independent nominating commission. Judges would then stand for yes/no retention elections to secure subsequent terms. As of this writing, HB 1336 is awaiting full consideration by the Pennsylvania House. 
Will HB 1336 pass? Will Pennsylvanians see an alteration to their judicial selection system in the near future? Historical and empirical evidence suggests not. Proponents of judicial selection reform have been actively lobbying the Pennsylvania legislature since the 1950s, yet the recent movement on HB 1336 is the first time since 1993 that selection reform legislation has passed at any level in the General Assembly. ${ }^{13}$ This does not suggest a historical record of legislative support for altering the state's judicial selection method. Empirical evidence from other states also casts doubt on Pennsylvania's prospects for reform. A recent study of successful and unsuccessful efforts to alter state judicial selection methods suggests there are two significant barriers to successful judicial selection reform in the states. Specifically, efforts to move a state from judicial elections to commission-based systems, or the Missouri Plan, are often derailed by a lack of substantial and sustained public support for the reform and state constitutional barriers that make moving away from elective methods more difficult for state legislatures (Bonneau and Kane, forthcoming). Unfortunately for proponents of HB 1336, Pennsylvania faces both barriers.

Most methods of judicial selection are established in state constitutions, by statute, or a mix of both. The Pennsylvania Constitution calls for judicial elections to be used to select judges, while the partisan nature of those elections is established by statute. Therefore, to abandon judicial elections altogether, the Pennsylvania Constitution must be amended, a process that requires full approval by both state houses in two consecutive sessions of the General Assembly and ratification by a majority of voters in a statewide referendum. The institutional barrier created by the constitutional amendment process is difficult to surmount as seen in recent failed reform efforts in Nevada and Minnesota. Not only will long-term political and legislative support be needed to move Pennsylvania away from judicial elections, the voter ratification process also means that widespread citizen support will also be needed if the state is to abandon judicial elections. As the spectacle of the 2015 Pennsylvania Supreme Court race fades from voters' memories, so too may the prospects for judicial selection reform.

\section{Concluding Thoughts}

The 2015 Pennsylvania Supreme Court race involved unprecedented levels of overall spending and outside interest group advertising. While Pennsylvania has long been a state with million-dollar high court contests, the $\$ 15.8$ million spent in the 2015 race exceeded previous spending records both within and across states. However, considering that three open seats were to be filled by the 2015 contest and that the partisan balance of the Pennsylvania 
Supreme Court would be determined by the race, this record-breaking spending came as no surprise to court observers and scholars of judicial elections. When viewed comparatively within the context of high-cost partisan judicial elections, the 2015 Pennsylvania race appears to be less historic and more a symptom of general trends in contemporary judicial campaigns, especially campaign advertising and outside interest group involvement.

\section{NOTES}

1. The three ads referenced here are titled "Covey Has a Problem," "Come under Criticism," and "Failed to Protect." All are available at www.brennancenter.org/analysis/ buying-time-2015-pennsylvania.

2. When comparing levels of spending in these two races, it is important to note that the 2004 race in Illinois involved only two general election candidates competing for a single open seat compared with the 2015 Pennsylvania race, which included seven candidates in the general election vying for three vacancies.

3. See Staub (2014) and Bumsted (2014) for more detailed explanation of the situations surrounding the departure of Justices Melvin and McCaffery. See Hall (2015) for a discussion of Justice Castille's retirement and his reflections on the scandals surrounding Justices Melvin and McCaffery.

4. Pennsylvania Department of State. "Campaign Finance Reporting Law" Available at www.dos.pa. gov/VotingElections/CandidatesCommittees/CampaignFinance/ Documents/Law-CF/law.pdf.

5. Rule 4.1(A) of Pennsylvania Code of Judicial Conduct, Available at http://judicial conductboardofpa.org/ code-of-judicial-conduct/.

6. Originally aired respectively as "Here They Are" and "Failed to Protect." Available at www.brennan center.org/analysis/buying-time-2015-pennsylvania.

7. See www.brennancenter.org/analysis/buying-time.

8. Data on the total number of airings of each ad were unavailable at the time of writing.

9. See Table 4.

10. The Brennan Center for Justice only recently began gathering advertising data for state supreme court races held in off-year election cycles.

11. Associations include the American Bar Association and the National Center for State Courts.

12. National groups include Justice at Stake and the now defunct American Judicature Society, while state specific groups include organizations such as Pennsylvanians for Modern Courts.

13. See the National Center for State Court's Judicial Selection in the States website for a list of failed reform efforts in Pennsylvania, www.judicialselection.com/judicial_ selection/reform_efforts/failed_reform_efforts.cfm? state=PA.

\section{REFERENCES}

American Judicature Society. 2010a. "Campaign Contributors and the Pennsylvania Supreme Court.” Available at www.judicialselection.us/uploads/documents/AJS_PA_ study_31810_rev_4BA9652A47AD2.pdf. Accessed July 15, 2016. 
2010b. "Opinion Polls and Surveys." Available at www.judicialselection.us/ judicial_selection/reform_efforts/opinion_polls_surveys.cfm?state=. Accessed July $15,2016$.

Baum, Lawrence. 2003. "Judicial Elections and Judicial Independence: The Voters' Perspective." Ohio State Law Journal 64: 13-41.

Benesh, Sarah C. 2006. "Understanding Public Confidence in American Courts." Journal of Politics 68 (August): 697-707.

Bishop, Tyler. 2015. “The Most Expensive Judicial Election in U.S. History.” The Atlantic, November 10.

Bonneau, Chris W. 2004. "Patterns of Campaign Spending and Electoral Competition in State Supreme Court Elections.” Justice System Journal 25 (1): 21-38.

- 2005. "What Price Justice(s)? Understanding Campaign Spending in State Supreme Court Elections." State Politics and Policy Quarterly 5 (Summer): 107-125.

Bonneau, Chris W., and Jenna Becker Kane. Forthcoming. "Proposals for Reforms: Successes and Failures." In Judicial Elections in the 21st Century, ed. Chris W. Bonneau and Melinda Gann Hall. New York: Routledge.

Bonneau, Chris W., and Melinda Gann Hall. 2003. "Predicting Challengers in State Supreme Court Elections: Context and the Politics of Institutional Design" Political Research Quarterly 56 (September): 337-349.

- 2009. In Defense of Judicial Elections. New York: Routledge.

Brennan Center for Justice. 2015. "Pennsylvania Logs Costliest Supreme Court Race in U.S. History." Brennan Center for Justice Press Release, November 3.

- 2016. Buying Time. Available at www.brennancenter.org/analysis/buying-time.

Bumsted, Brad. 2014. "Pa. Supreme Court in 'Sad State' as Scandals Tarnish Reputation." Available at triblive.com/state/pennsylvania/7002858-74/court-justice-pennsylvania. Accessed October 25.

Cann, Damon M. 2002. "Campaign Contributions and Judicial Behavior." American Review of Politics 23 (Fall): 261-274.

_. 2007. "Justice for Sale? Campaign Contributions and Judicial Decisionmaking." State Politics and Policy Quarterly 7 (Fall): 281-297.

Cann, Damon M., Chris W. Bonneau, and Brent D. Boyea. 2012. "Campaign Contributions and Judicial Decisions in Partisan and Nonpartisan Elections." In New Directions in Judicial Politics, ed. Kevin T. McGuire. New York: Routledge.

Citizens United v. Federal Election Commission. 2010. 558 U.S. 310.

Dimino, Michael R. 2004. “The Futile Quest for a System of Judicial 'Merit' Selection.” Albany Law Review 67: 803-819.

Geer, John G. 2006. In Defense of Negativity: Attack Ads in Presidential Campaigns. Chicago: University of Chicago Press.

Gibson, James L. 2012. Electing Judges: The Surprising Effects of Campaigning on Judicial Legitimacy. Chicago: University of Chicago Press.

Goelzhauser, Greg. 2016. Choosing State Supreme Court Justices: Merit Selection and the Consequences of Institutional Reform. Philadelphia: Temple University Press.

Greytak, Scott, Alicia Bannon, Allyse Falce, and Linda Casey. 2015. The New Politics of Judicial Elections 2013-14. Washington, DC: Justice at Stake Campaign.

Hall, Melinda Gann. 2001. "State Supreme Courts in American Democracy: Probing the Myths of Judicial Reform.” American Political Science Review 95 (June): 315-330.

_ 2007. "Competition as Accountability in State Supreme Court Elections." In Running for Judge: The Rising Political, Financial, and Legal Stakes of Judicial Elections, ed. M. Streb. New York: New York University Press. 
- 2015. Attacking Judges: How Campaign Advertising Influences State Supreme Court Elections. Stanford, CA: Stanford University Press.

Hall, Peter. 2015. "Retiring Chief Justice Castille Says He Kept Faith in Fellow Jurists." Morning Call, January 10.

Hansen, Mark. 1998. "A Run for the Bench.” ABA Journal 84 (October): 68-72.

Kritzer, Herbert M. 2011. "Competitiveness in State Supreme Court Elections, 19462009.” Journal of Empirical Legal Studies 8 (June): 237-259.

National Center for State Courts. 2016. Judicial Selection in the States. Available at www .judicialselection.us. Accessed May 30, 2016.

O'Connor, Sandra Day. 2008. "Choosing (and Recusing) Our State Court Justices Wisely: Keynote Remarks by Justice O'Connor.” Georgetown Law Journal 99: 151.

Philadelphia Inquirer Editorial Board. 2015. "Low Road to High Court." Philadelphia Inquirer, November 9.

Pittsburgh Post-Gazette Editorial Board. 2015. "Low Blows: Negative Ads Have No Place in Supreme Court Race.” Pittsburgh Post-Gazette, October 20.

Potter, Chris. 2015. "Special Interest Groups in Pennsylvania Funding Ads Targeting State Supreme Court Candidates." Pittsburgh Post-Gazette, October 17.

Sample, James, Adam Skaggs, Jonathan Blitzer, and Linda Casey. 2010. The New Politics of Judicial Elections 2000-2009: Decade of Change. Washington, DC: Justice at Stake Campaign.

Shepherd, Joanna M. 2009. "Money, Politics, and Impartial Justice." Duke Law Journal 58 (January): 623-685.

- 2013. Justice at Risk: An Empirical Analysis of Campaign Contributions and Judicial Decisions. Washington, DC: American Constitution Society.

Skaggs, Adam, Maria da Silva, Linda Casey, and Charles Hall. 2011. The New Politics of Judicial Elections, 2009-2010. Washington, DC: Justice at Stake Campaign.

Staub, Andrew. 2014. "Justices Behaving Badly: PA Supreme Court has Embarrassing History." Available at watchdog.org/178529/supreme-court-pennsylvania/. Accessed October 22.

Jenna Becker Kane, $\mathrm{PhD}$, is an assistant professor of political science at West Chester University, where she teaches courses on judicial politics, constitutional law, and political institutions. Her research interests include state supreme court decision making, interest group involvement in state courts, and judicial elections. Her publications include several coauthored pieces, including a forthcoming book chapter on state judicial selection reform. 